\title{
Men, masculinity and anti-feminist violence at the post-conflict frontier, Nagaland, India
}

Edition 6, 2021

Dr Matthew Wilkinson

DOI: 10.37839/MAR2652-550X6.1

In the wake of ceasefires signed in the late 1990s and early 2000s, the state of Nagaland, India is undergoing a process of liberalisation involving closer economic ties to India, expanding consumer markets, new welfare services and infrastructure provided by the Government of India, and new settlers coming to the frontier state. Liberalisation in the wake of conflict has also been of immense benefit to Nagaland, encouraging economic growth, new livelihood opportunities, and migration between Nagaland and India's heartland alongside other Northeast Indian states.

However, closer connections with India, new mobilities, and increased migration into and out of the post-conflict frontier state have also resulted in new forms of contestation, as a rigidly-gendered social order is questioned by some and argued by others to be a fundamental aspect of Naga society. Change at the frontier has brought gender to the fore as a central and contested political issue. Essentially, a new and mutually exclusive binary has emerged in Nagaland, between inclusive feminist models of citizenship, and the essence of what it means to be Naga.

\section{Nagaland}

Nagaland is located in Northeast India, a geographically distinct region of India wedged between China, Bhutan, Burma, and Bangladesh. The Northeast constitutes the states of Assam, Meghalaya, Manipur, Tripura, Mizoram, Arunachal Pradesh, 
Sikkim and Nagaland. Most of these states, Nagaland included, were once a part of Assam, and were carved into distinct states in the 1960s, 1970s, and 1980s as a concession to demands for various forms recognition and autonomy made by a number of distinct ethnic groups in the Northeast. In 1963 Nagaland was the first of these states to become separate from Assam. Before statehood, Nagaland was governed as the Naga Hills District of Assam (formed in 1866) and the Tuensang Division of the North East Frontier Agency (formed out of the Naga Hills District in 1948). This District encompassed the highlands overlapping the border of presentday India and Burma, bounded on western side by the Assam plains in India and on the eastern side by the plains east of the Chindwin River in Burma. 


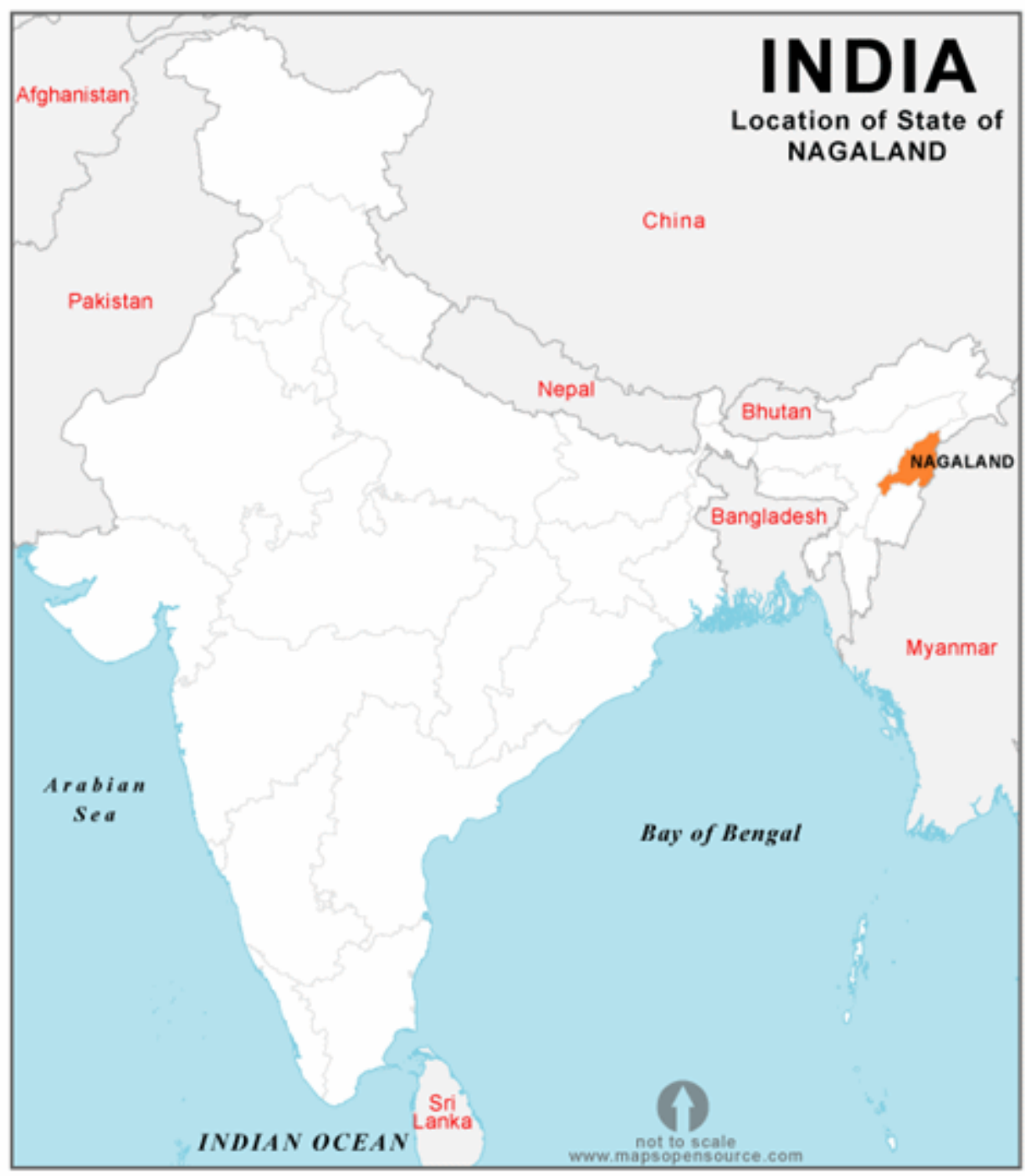

Nagaland's current borders approximately reflect these original boundaries. The highlands that form the Naga Hills constitute part of what scholar Willem van Schendel coined as Zomia, a term later endorsed by political scientist and anthropologist James C. Scott. 'Zomia' refers to a contiguous mountainous region extending from Indochina to Central Asia, defined by its difficult and rugged geography, distance from state centres, and populations who have often migrated to the highlands to evade oppressive states. These remote communities have 'shared ideas, related lifeways, and long-standing cultural ties' that greatly differ from communities living in the neighbouring lowland plains, such as the forms of 
agricultural they practice and religious, linguistic, and often physical differences to lowland settled populations.

Official figures show that Nagaland is home to approximately 2.2 million people. Tribal communities constitute 86.5 percent of this population. There are sixteen tribes in Nagaland recognised by the Government of India, although there are also several communities who identify as tribes but are not officially recognised as such. Naga tribes trace their lineages to Southwest China, Tibet, and the Arakan ranges in Burma. The remaining 13.5 percent includes migrants from Assam, Bengal, Bihar, a large community of Marwari traders, and communities from Nepal, Bhutan, and Bangladesh. Nagaland is a predominantly Christian state, where 87.9 percent of the population identify as Christian, most often Baptist or Evangelical.

Naga society is highly patriarchal. Long-held cultural and political norms designate men as the embodiment and leaders of their respective tribes and clans, and women as tethered to the identities of their fathers and husbands. Naga society is marked by a rigid compartmentalisation of gender roles and responsibilities, whereby men are regarded as having a natural propensity towards leadership, managing land and resources and conducting warfare, and women are naturally better at roles associated with maintaining households, raising children, and supporting and obeying men. This is commonly referred to in Nagaland as 'equality as tradition'.

Since 1947, Nagaland has been embroiled in an intense conflict between Naga nationalist groups agitating for various forms of independence and the Government of India attempting to maintain its sovereignty over Nagaland. Throughout the conflict, Indian paramilitaries have indiscriminately targeted Naga communities in efforts to flush out Naga insurgents and to identify and punish people harbouring and assisting them. This has often involved burning villages and crops to clear settlements and 'starve out' suspect communities, especially in the 1950s and 1960s. Rape and sexual violence have been employed widely to intimidate Naga communities, humiliate Naga women, and emasculate Naga men. 
In the 1970s, 1980s, and early 1990s, Nagaland's conflict became entangled with tribal feuds and clan wars, as Naga nationalist groups divided along ideological and tribal lines. In 1980, a division occurred in the Naga National Council (NNC), once the sole Naga nationalist group, as members formed a competing insurgent group, the National Socialist Council of Nagalim (NSCN) (a reference to a loosely drawn Naga-Lim, or Naga homeland endorsed by the NSCN). In 1989 the NSCN divided along ideological lines, forming the two largest insurgent groups in Nagaland today, one NSCN faction led by Isak Chishi Swu and Thuingaleng Muivah (NSCN-IM) and an opposing NSCN faction led by S. S. Khaplang (NSCN-K).

In 1997, a ceasefire was agreed between the NSCN-IM and the Government of India. In 2001, a second ceasefire was agreed with the NSCN-K and the Government of India. These ceasefires officially marked an end to open hostility between Naga nationalist groups and the Indian state, although Nagaland continues to be governed through military priorities and fighting between competing Naga nationalist factions continues.

Since ceasefire, Nagaland has opened up in a number of ways and is liberalising at an accelerating rate. Restrictions on entry into the state have been relaxed as the Nagaland state government attempts to encourage a lucrative tourism industry. New businesses are opening and attempting to establish themselves in the state's emerging post-conflict economy. Many goods and services are more available than before, including high-end consumer technologies such as computers and phones imported from China and South Korea. Indian development funds are coming into the state with the goal of upgrading connective infrastructure and promoting 'peacethrough-development' through greater regional engagement.

Essentially, the frontier is being redefined and reoriented from a space marked by isolation, conflict, and very few livelihood options to being more connected and commercially engaged, with new mobilities and more jobs. This process is uneven, and occurs alongside ongoing militarisation, bandhs (general strikes) announced by non-state armed groups, and continuing state dysfunction; but it is ongoing and 
accelerating nonetheless.

\section{Gender, contestation and change at the Indo-Burmese frontier}

Changes in Nagaland since ceasefire have raised new challenges and questions for Nagaland's deeply embedded patriarchal traditions, especially in relation to Nagaland's rigidly gendered social structures. New opportunities in the post-conflict frontier offer Naga women, in particular, new freedoms, mobilities, and forms of empowerment. They are more able to find employment in the post-conflict economy, and in many cases leave their communities to work and study in other parts of India, or overseas. In interviews conducted for my own research between 2016 and 2020 in many Naga households, the women were often the primary breadwinner, while younger men especially found it difficult to find employment outside of highly competitive government work. This was a problem that men often attributed to opportunities and lucrative jobs being 'captured' by elites and people with access to elites. Essentially, the post-conflict economy is perceived by many Naga men as having delivered a number of new opportunities for women in the Naga community while the opportunities for Naga men have either not been delivered or have been captured by a small group of tribal elites.

In light of these post-conflict changes, challenges to Nagaland's rigidly gendered model are becoming more prominent. Naga women's rights organisations, such as the Naga Mothers Association (NMA), agitate for rights to take part in community decision-making and inherit ancestral property. Naga women are also running for state parliament, although Nagaland's legislative assembly has not had a female member since 1978.

These challenges to Nagaland's customary institutions and norms have met with vehement and violent resistance. Women who speak out against patriarchal traditions or who speak in favour of inclusive change are often chastised in public, 
and risk being rejected by their communities. In 2017, eight women from Phek District, in Nagaland's rural 'interior', were threatened with banishment from their villages for attempting to run in state elections.

As well as banishing women who overstep traditional gender roles and chastising outspoken women, Naga elites and elders have encouraged intensive efforts to monitor, police, and control the movements and relationships of Naga women. Women who defy traditions relating to relationships within the Naga community, and instead form relationships with and/or marry outsiders, especially those of Bengali or Bangladeshi heritage, are subject to ostracism. This was raised during a speech by Nagaland's Chief Minister, Neiphiu Rio on January 12, 2019, who raised the possibility of stripping Naga women of their tribal status if they marry non-Nagas, effectively rescinding their identities as Naga.

Resistance to change to Nagaland's patriarchal traditions came to a head in 2017 over women's reservations for Urban Local Body elections. In November 2016, Guwahati High Court found that Nagaland was under the purview of Article 243T of India's Constitution, essentially requiring that municipal bodies reserve 33 percent of seats for women in Urban Local Body elections. Throughout the High Court deliberations tensions flared in Nagaland, where many felt the reservations contravened Nagaland's patriarchal customary traditions. On January 31, 2017, two youths in Dimapur were killed by police while protesting the enforced reservations, and twelve others were injured. A few days later, violence erupted throughout Nagaland. Protestors blockaded streets and rampaged through Nagaland's larger cities, Kohima and Dimapur, as well as several smaller towns that were not the subject of the Urban Local Body elections. In the ensuing violence a municipal government building was set alight. Nagaland's then Chief Minister, T.R. Zeliang, was forced to resign as a result of the protests and the Urban Body Elections were postponed indefinitely. Interviews with Naga men and women in Kohima in the week following the February riot brought to surface a consensus among several Naga conservatives that the pushes for women's reservations were led by 'trouble-making' women, 'spinsters' and 'divorced women' who had been influenced by outside actors. 


\section{Gender, liberalisation, and conflict in Asia}

The changes taking place in Nagaland, while unique in many ways, reflect the politics and anxieties of other frontiers and borderlands. Contestations over gender and identity in Nagaland are similar to the gendered nature of neoliberal transformations in other Asian and South Asian frontiers, and the ways issues of identity and gender are magnified at frontiers. As these sites undergo processes of liberalisation, patriarchal structures and systems are increasingly being questioned and challenged. As such, responses to changing gender norms, the transgression of pre-existing norms, and challenges to rigidly gendered resource control regimes are magnified at these sites. In neighbouring Myanmar for example, processes of democratisation, attached to liberalisation and the opening of Myanmar's markets to global trade have resulted in divisions between feminists and human rights activists agitating for more legislation to promote women's representation in parliament, and those who regard women's rights as anti-national. Likewise, microcredit programs in Bangladesh that aim to promote women's empowerment through encouraging smallscale entrepreneurship have been associated with a rise, rather than a fall, in intimate partner violence and with localised resistance to women's economic empowerment.

Essentially, economic and social changes taking place in Nagaland are similar to those associated with liberalisation in other areas. The value of looking at Nagaland to understand these changes is found in Nagaland's complex gendered politics, which, following decades of armed conflict, are open to challenge-and resistance to change.

Influential American feminist Susan Faludi refers to the resistance to this change in Western contexts as a 'patriarchal backlash'-when women breach traditional 'women's spaces' and transgress home-based roles, there is a trend of resistance through media, in politics, and at the household level in an attempt to 'resubjugate' women. Other studies have provided some support for this hypothesis. Temple 
University Scholar E.F Avakame found that the backlash hypothesis offers a compelling explanation for increased rates of violence against women in the US as women's participation in the workforce increases. Ethnographic studies have provided further insight into the backlash theory. In one of the most widely cited examples, Kerry Carrington and John Scott found that amid 'sweeping social changes to rural life' men in rural Australia, an interior frontier in many senses, 'resort to violence as a largely strategic practice deployed to recreate an imagined rural gender order'. While, on the whole, violence against women is negatively correlated with rising women's wages and economic activity, in cases where women transcend established gender norms and become more economically independent and politically empowered, in some cases more than the men in their lives are, a backlash takes place in the form of domestic violence, stringent checks and controls over movements, and increased surveillance of women.

Backlash is much more complex than men feeling threatened by women staking a greater control over household resources and exercising some forms of employmentlinked independence. Carrington \& Scott recognise this complexity, arguing that insecurities linked to masculinities are not just about the erosion of male status, power, or identity, but the way in which gendered aspects of social organization are structurally threatened by much larger historical destabilizations, and the complex psycho-social reactions of men to these events'. In other words, the patriarchal backlash not only stems from women's empowerment relative to men at the household level, but encompasses wider disruptions to established gender norms, concerns about identity and ethnicity, and attachments to gendered systems which, while being oppressive, provide a clear sense of purpose and place. Philosopher Filipa Melo Lopes refers to this as a post-feminist backlash, marked by enforcement of patriarchal gender norms by men and women onto any person breaching them.

Nagaland's patriarchal backlash offers new insights into these understandings. In the wake of ceasefire, many patriarchal norms and customs are being questioned and challenged by groups within the state, such as Naga women, and entities outside of the state, namely, the Government of India. This takes place in a context where 
decades of militarisation and economic stagnation, although changing, leaves limited avenues for Naga men to satisfy masculine norms involving finding and keeping work and acting as guardians of Naga territory, culture, and society from outside incursions. Aptly stated by scholar and activist Rita Manchanda:

'In a society that traditionally was locked in endemic war cycles (involving headhunting) male value was marked by the physical prowess to fight. The protracted experience of living under the virtual rule of the Indian security, has emasculated Naga men's self-perception of their role as protectors. There is a crisis of 'masculinity' that is reinforced by the opening up of new roles of agency for women. It also predicates a backlash'.

Patriarchal backlash in Nagaland is closely tied to efforts to preserve Indigenous rights, embodied in patriarchal customary institutions and a rigidly gendered understanding of Naga society. A change to one is seen as a threat to the other. Changes in the state in the wake of ceasefire have in many ways further upset Naga cultural norms and a narrowly drawn understanding of Naga society. Many Naga men felt emasculated under a disempowering military occupation and Naga women are exercising greater degrees of economic empowerment, independence, and agency. Furthermore, the belief that agitators for inclusive change are corrupted or are otherwise influenced from the outside is widespread. Patriarchal norms in Nagaland are considered by many as a stable bedrock of Naga society that cannot be compromised, and hence, when challenged, attracts a widespread and violent backlash. In Nagaland, gender has becoming highly politicised, as the post-conflict economic liberalisation of the state stokes anxieties about control of the future, and elites and conservatives assert that maintaining a rigidly gendered social order is key to the survival of Naga society.

Image: Flyover' at Dimapur, Nagaland, February 2016. Credit: author.

Map credit: mapsopensource. 